\title{
Complete and Partial Organizing for Corporate Social Responsibility
}

\author{
Andreas Rasche - Frank G. A. de Bakker • \\ Jeremy Moon
}

Published online: 7 August 2013

(C) Springer Science+Business Media Dordrecht 2013

\begin{abstract}
This paper investigates different modes of organizing for corporate social responsibility (CSR). Based on insights from organization theory, we theorize two ways to organize for CSR. "Complete" organization for CSR happens within businesses and depends on the availability of certain organizational elements (e.g., membership, hierarchy, rules, monitoring, and sanctioning). By contrast, "partial" organization for CSR happens when organizers do not have direct access to all these organizational elements. We discuss partial organization for CSR by analyzing how standards and cross-sector partnerships make selective use of organizational elements. We maintain that an important feature of the increasing institutionalization of CSR - not only within businesses but also among nongovernmental, governmental, and professional actors-is the rise of partial forms of organization. We discuss the contributions to this Special Issue in the context of our theorization of complete/partial organization for CSR and outline avenues for further research.
\end{abstract}

\footnotetext{
A. Rasche $(\square)$

Copenhagen Business School, CBS Centre for Corporate Social Responsibility, Porcelænshaven 18A, 2000 Frederiksberg, Denmark

e-mail: ara.ikl@cbs.dk

F. G. A. de Bakker

Department of Organisation Sciences, Faculty of Social Science,

VU University Amsterdam, De Boelelaan 1081,

1081 HV Amsterdam, The Netherlands

e-mail: f.g.a.de.bakker@vu.nl

J. Moon

International Centre for Corporate Social Responsibility (ICCSR), Nottingham University Business School, Jubilee Campus, Wollaton Road, Nottingham NG8 1BB, UK

e-mail: Jeremy.Moon@ nottingham.ac.uk
}

Keywords Organization studies · Corporate social responsibility $\cdot$ CSR standards $\cdot$ Cross-sector partnerships $\cdot$ Partial organization · Institutional theory $\cdot$ Complete organization

\section{Introduction}

How is corporate social responsibility (CSR) organized? Why are certain organizational forms used frequently to coordinate CSR activities, while other forms are less widespread? Students of CSR and organization studies rarely address such questions despite the emergence of CSR as an academic field (de Bakker et al. 2005; Lockett et al. 2006). A lot is known about CSR, particularly of multinational corporations (MNCs) (Maignan and Ralston 2002; Chapple and Moon 2005); the business benefits of CSR (Aguinis and Glavas 2012; Carroll and Shabana 2010); civil society involvement (den Hond and de Bakker 2007); as well as the politicization of CSR (Moon et al. 2004; Scherer and Palazzo 2011) and its links with globalization (Gilbert et al. 2011). However, CSR scholars have tended to overlook, or take for granted, the respective organizational components of these developments.

The CSR literature is now well-stocked with studies of particular initiatives such as cross-sector partnerships, codes of conduct, and multi-stakeholder standards. However, the elements that enable and constrain these organized orders are rarely considered. For instance, some types of organizing for CSR make explicit reference to hierarchy by obliging others to comply with central decisions (e.g., when a firm introduces a code of conduct), while other types of organizing for CSR neglect hierarchical steering (e.g., when corporations and NGOs enter into partnerships). Few scholars have looked into why, 
when, and how certain organizational elements like hierarchy are used to coordinate CSR-related activities within and among organizations.

We argue that there is value in examining the organizational features of CSR developments more closely. After all, businesses address social and environmental issues through different types of organizing (Husted 2003). For instance, firms can promote human rights through in-house projects, partnership agreements, or by signing up to industry-wide standards (Abbott 2012). When and why are certain types of organizing for CSR preferable to other types? On what grounds do actors decide how to organize for CSR in a given situation? While we do not claim to have conclusive answers to these questions, in this paper we offer a theoretical framework, based on insights from organization theory, to approach this discussion systematically.

Our argument takes as a starting point Ahrne and Brunsson's (2011) recent claim that the concept of organization can be better understood once the organizational elements that are needed to achieve organized orders are unpacked: i.e., membership, hierarchy, rules, monitoring, and sanctioning. Whereas formal organizations typically have access to all these elements, other types of organizing only use selected elements. Drawing on these ideas, we argue that two types of organizing for CSR stand out. First, CSR can be organized through "complete" organization in businesses such as in MNCs and small and medium-sized enterprises (SMEs). In such cases, organizers usually have access to all organizational elements, although the way in which these elements are operationalized may differ in style among larger corporations and SMEs. Second, CSR can be organized through "partial" organization, such as CSR standards (e.g., the Forest Stewardship Council) and partnerships (e.g., between NGOs and corporations). In these cases, organizers do not have access to all organizational elements. When discussing complete/partial organization for CSR, we refer to the process of applying and mixing different organizational elements while organizing for CSR.

This paper suggests, first, that it is necessary to analytically distinguish these two types of organizing for CSR. Second, we argue that being selective among the organizational elements available, can be advantageous for CSR organizers (e.g., in terms of reduced costs), but can also create challenges for managing CSR (e.g., in terms of missing accountability). Third, the paper reveals how the focus upon organizing for CSR, whether inside or outside formal organizations, complements other theoretical approaches in the field. In particular, it relates the theory of "organizing" to institutional theory which has recently seen some shift toward interaction dynamics in multiinstitutional systems (Thornton et al. 2012), including between social movements, civil society, and corporations (de Bakker et al. 2013). Fourth, we argue that the rise of partial modes of organizing for CSR has been part of a more general shift from CSR being "corporate-centered" to a more "corporate-oriented" understanding. On the basis of these four contributions, we argue that a new direction of CSR research emerges, a direction that puts more emphasis on how CSR organizers (e.g., firms, NGOs, standard-setters, governments) (re-)combine different organizational elements to achieve their goals.

This paper proceeds as follows: in the next section we introduce the theoretical background of the overall argument by revisiting relevant theoretical frameworks in organization studies. The following section introduces two different ways of organizing for CSR, distinguishing between "complete" organization and "partial" organization. We provide a variety of examples of how both forms of organizing create opportunities and problems for CSR. The next section outlines new avenues for research at the intersection of organization theory and CSR by introducing the papers in this Special Issue. In the concluding section, we briefly outline an agenda for future research in this area.

\section{Theoretical Background}

\section{Complete and Partial Organization}

When reflecting on how something is organized, it makes sense to distinguish between "the organized" and the "non-organized". What criteria enable this distinction? According to Ahrne and Brunsson (2011), organization can be understood as a type of decided social order in which one or more of the following elements exist: membership, hierarchy, rules, monitoring, and sanctions. Our analysis of organizing for CSR is based on a discussion of these five organizational elements.

Traditionally, scholars have focused on organizing that happens within the boundaries of formal organizations (Etzioni 1964; March and Simon 1958; Mintzberg 1979; Weick 1979). Formal organizations possess all five elements and thus can be characterized as "complete" organizations. For instance, formal organizations decide about who can and cannot join the organization (e.g., as an employee) and thus constitute their membership. They also assign decision-making authority to certain individuals or groups of individuals and hence include some form of hierarchy (Child 2005). Formal organizations also coordinate their activities by issuing rules that members are expected to follow and establish formal or informal monitoring mechanisms to ensure rule compliance (Weber 1968). Finally, formal organizations contain positive and negative sanctioning mechanisms, both of which reflect an additional way to enforce relevant rules. Of course, the 
extent to which these five elements are deployed in any formal organization, and their overall balance therein, remain empirical questions. What is important for our analysis is that formal organizations by definition can draw on all five elements to create a decided order (Ahrne and Brunsson 2011; Brunsson 2006). Even if they choose not to draw upon all elements for a particular organizational task, the latent possession of the full range of elements constitutes the distinguishing feature of complete organization.

However, not all organization takes place within the boundaries of formal organizations. Organization also occurs when one or several of the described elements of formal organizations are missing. Ahrne and Brunsson (2011, p. 84) make exactly this point when arguing that "[w]e can find organization not only within, but also outside and among formal organizations." For instance, formal organizations can organize other organizations (e.g., associations), and the environment of formal organizations can also contain elements of organization (e.g., when looking at standards that are adopted by different organizations). Hence, it is possible to distinguish two types of organization: "complete" formal organizations (i.e., organizations containing all of the elements constitutive of organization) and "partial" organization (i.e., those forms of organization that only use selected elements). Partial organization comes in different forms. For instance, rankings of business schools reflect one form of partial organization. While rankings monitor schools' behavior, have sanctioning effects and are based on explicit rules (Sauder and Espeland 2009), they do not necessarily organize through membership or hierarchical control. Associations reflect another type of partial organization. While they organize through membership and also specify certain rules that members need to adhere to, they usually do not monitor or sanction members' behavior (Coleman 1997).

Recognizing that organization can stretch beyond the boundaries of formal organizations throws up the question of how organization is different from two other prominent concepts in organization studies: networks and institutions. While Ahrne and Brunsson (2011) realize that networks and institutions can be defined in broad terms making it hard to distinguish them from organization, they also point to an important difference. Networks and institutions constitute emergent social orders. Institutions emerge through habituation of interactions (Berger and Luckmann 1966) and are "stable, valued recurring patterns of behavior" whose levels of institutionalization reflect their adaptability, complexity, autonomy, and coherence (Huntington 1968, p. 12). Likewise, social networks develop gradually and depend on mutual trust (Granovetter 1973).

By contrast, organization, whether partial or complete, is the result of deliberate decisions by individuals or by other organizations (e.g., when deciding to introduce an ethical supply system). ${ }^{1}$ The fact that organization is the result of deliberate decisions has a variety of implications. For instance, whereas institutions are usually not questioned, as they reflect taken-for-granted patterns of behavior, organized orders can be challenged more easily due to the explicit nature of the underlying decisions. Furthermore, since deliberate decisions emphasize human control (as they are the outcome of individuals' preferences), responsibility is easier to assign when looking at organized orders. By contrast, in emergent orders responsibility is less concentrated around individual decisions and hence more dispersed and diluted (Ahrne and Brunsson 2011, p. 91).

\section{Corporate Social Responsibility}

CSR has been described as an "essentially contested" concept which means that even its adherents may disagree as to its scope and application (Gond and Moon 2011). As various surveys of the field have revealed, there have been numerous different theoretical orientations for CSR, such as the instrumental, the political, the integrative (or stakeholder), and the ethical approaches (Garriga and Melé 2004; de Bakker et al. 2005). There have also been a number of disputes in understanding CSR, particularly concerning its relationship with profit making, with the law, and with government policy.

Tracing CSR as a coherent management concept and as an academic field therefore is a somewhat fraught exercise. The 2011 European Commission (2011, p. 6) definition captures its essence: "the responsibility of enterprises for their impacts on society." However, CSR has varied enormously by context, particularly the context of place, or national business systems (Matten and Moon 2008). Moreover, the most important characteristic to note in CSR is its susceptibility to change (Gond and Moon 2011). Change has been evident through variations in: the relative significance of Garriga and Melé's (2004) theoretical positions on CSR; the balance of importance attached to the different levels of responsibility in Carroll's (1979) CSR pyramid; the variable prioritization of particular stakeholders (be they society, investors, consumers, employees-including those in supply chain companies); and the balance of social, economic,

\footnotetext{
${ }^{1}$ We are aware that not all scholars would agree to describe institutions as emergent social orders. Peters (1999, p. 18), for instance, understands institutions as "structural features of the society/polity," which also includes deliberately created elements such as legislatures. Meanwhile, some networks are also deliberately organized-think of networks of NGOs working in a specific campaign (de Bakker 2012). It is important to note in this context that Ahrne and Brunsson (2011) argue that in genuine networks and institutions organizational elements are absent. In many cases, organizational elements are introduced in order to change or control institutionalized orders or network relations.
} 
environmental, and governance criteria used in assigning and claiming responsibility.

In the context of our interest in organizing CSR, the most important dynamic can be summed up as a shift from CSR principally being a more "corporate-centered" to a more "corporate-oriented" concept (Moon 2014). Fifty years ago, CSR would have been regarded by many as essentially a matter of corporate discretion quite removed from the requirements of the law or public policy (McGuire 1963). The corporation decided how its responsibility would be enacted and that it was responsible for implementing such decisions. As such, the organization of CSR was almost entirely conducted through complete organization, i.e., the corporation. This is not to say that other actors were entirely uninvolved in CSR. Community bodies and charities who were recipients of CSR, which was mainly in the form of philanthropy, would have played some role in its organization. But relative to the subsequent change in CSR, which we depict below, the organization of CSR was "corporate-centered."

In contrast, CSR is now better conceptualized as a "corporate-oriented" phenomenon in which the focus is upon responsibility in the sphere of the corporation, including for its supply chain, for its own practices (e.g., employment, use of resources), and for the consumption and disposal of its products and services. This broadening of the conception of CSR from that defined by the corporation itself (i.e., usually philanthropic outputs) has been associated with interest in responsibility in the sphere of the corporation among a much wider set of actors, including governments, civil society organizations, professionals, and wider businesses. These actors tend to organize their interest in CSR by what Ahrne and Brunsson (2011) would call partial organization, ranging from setting membership rules for partnerships to monitoring and imposing sanctions on ir/responsible company behavior. Today's CSR still contains elements of complete organization. After all the corporations are deemed responsible for actions in their name and take "explicit" responsibility for these (Matten and Moon 2008). Moreover, there is evidence that they are investing in their own CSR capacity. This is evident in alignment of CSR with corporate aims and strategy, dedicated CSR personnel and sub-organizational units, budgets, procedures (Moon 2004; see also Bondy et al. 2012; Strand 2012). However, it is now also organized by and with external actors such as other businesses (e.g., in an association such as Business in the Community UK), governmental or civil society partners, who bring new forms of organization, norms, incentives, and roles (Moon 2004). This tension reflects the fact that CSR is now as much about the social, governmental, and multi-actor regulation of business as about self-regulation of companies for community benefit.
Explanation of the changes in CSR from a more "corporate-centered" to a more "corporate-oriented" concept, which underpin the shift from complete organization for CSR to the contemporary pattern in which more partial organization is evolving, is difficult to pin down. It reflects a lot of different actors into scope reflecting both an increasing "socialization of markets" and changing forms of "national and global governance" (Moon 2014). Our point here is not the explanation but the recognition that in such forms of CSR, the corporation is not the sole actor, but operates with others who bring complementary resources, including knowledge and legitimacy. Partial organization for CSR not only involves partnerships (e.g., between NGOs and firms), CSR standards (e.g., the Global Reporting Initiative), but also regulation through government policies (e.g., for reporting environmental, social and governance impacts; Gond et al. 2011). Such initiatives frame the organization of CSR. Yet, these initiatives organize CSR very differently from what would have been expected of complete organization. Hence, it is useful to unpack the difference between complete and partial organization for CSR in more detail.

\section{Organizing CSR: Complete and Partial Organization}

\section{Organizing CSR Through Complete Organization}

Those discussing what activities constitute CSR have often looked inside formal organizations, in most cases MNCs (Jamali et al. 2009). Looking at CSR within corporations implies to focus on formal, "complete" organizations that usually have access to all organizational elements, although firms may use these elements to different degrees. While research has not yet discussed the relationship between the full range of organizational elements and CSR in an integrated way, numerous studies have provided insights into how selected elements impact the organization of CSR within firms.

Corporations decide about membership determining who is allowed to join the organization and who is excluded (Ahrne 1994). Membership affects the identity of a corporation and thus influences its understanding of CSR. Corporate identity, understood as shared perceptions leading to a certain degree of "perceived oneness with a group" (Ashforth and Mael 1989, p. 35), can guide the development of CSR activities that are congruent with how managers view themselves and their organization. Basu and Palazzo (2008), for instance, suggest that an organization's identity orientation is likely to influence the kind of relationships that it builds with stakeholders. Drawing on Brickson's (2007) work, they distinguish between an individualistic orientation (emphasizing individual liberty 
and self-interest), a relational orientation (emphasizing partnering with stakeholders), and a collectivistic orientation (emphasizing the role of organizations as part of society at large). Who belongs to an organization (i.e., its membership) has an influence on these orientations and hence determines how an organization will organize its CSR activities. For example, a firm with a relational identity orientation is likely to emphasize CSR actions that are based on building strong links with key stakeholders, while a corporation with an individualistic orientation might opt for activities that showcase its CSR performance as "best in class" (Basu and Palazzo 2008).

Corporations organize for CSR by making reference to some form of hierarchical steering. Hierarchy implies "a right to oblige others to comply with central decisions." (Ahrne and Brunsson 2011, p. 86) This right can be exercised in formal and informal ways and by different individuals/groups within the organization. Hierarchy does not necessarily imply that CSR is managed by using a command-and-control approach. Although CSR policies are usually backed by central decisions and are mostly defined by top-management (Singh 2011b), there are different ways to ensure compliance with these decisions, including the use of another organizational element, monitoring (see below). For instance, managers can use transactional or transformational leadership styles when organizing for CSR (Burns 1979). Transactional leadership gives more reference to formal power and rests on the belief that leaders motivate through explicit rewards and receive performance in return. Transformational leadership styles are less focused on formal incentives and instead emphasize individualized consideration, inspirational motivation, and intellectual stimulation (Strand 2011). Hence, hierarchical steering can be exercised in different ways, especially when considering the diversity of leadership styles for CSR (see also Pless et al. 2012).

Formal organizations also decide upon explicit rules that members are expected to follow. According to Weber (1968), rules provide for consistency, as decisions made in one part of the organization can be executed in another part. Corporations have given themselves rules that are supposed to codify "what counts" as responsible behavior in the context of the organization. These rules are usually called "codes of conduct" (or "codes of ethics"). Langlois and Schlegelmilch (1990, p. 522) define such codes as "a statement setting down corporate principles, ethics, rules of conduct, codes of practice or company philosophy concerning responsibility to employees, shareholders, consumers, the environment, or any other aspects of society external to the company." The prevalence of such rules has been increasing with $86 \%$ of the Global Fortune 200 currently having their own code (Singh 2011a). Research shows that the content and language of codes converge across organizations, as there seems to be a "cut and paste" mentality (Holder-Webb and Cohen 2012) reflecting coercive isomorphisms and mimetic practices (Matten and Moon 2008). This raises the question of whether organizations actually implement codes or whether code development is a mere symbolic act. Stevens et al. (2005) find that codes are integrated into decision-making when market actors (e.g., shareholders) pressure firms to take a code seriously and when it is integrated into routine activities (e.g., via training programs). Of course, codes are just one possible way to communicate expectations regarding responsible behavior within a corporation. The rules underlying CSR can also be fixed through other formal and informal mechanisms (e.g., contracts and standard operating procedures).

Monitoring is often believed to be a necessary organizational element to ensure code effectiveness (Petersen and Krings 2009). Because legislation in some countries requires firms to monitor the effectiveness of codes (e.g., the Sarbanes-Oxley Act in the U.S.; Kaptein and Schwartz 2008), there has been an increased emphasis on compliance mechanisms in recent years. Singh (2011b), for instance, finds that more than half of all Canadian firms use internal audits to monitor compliance with their codes. However, monitoring, when viewed as an organizational element, can take many forms besides auditing. For example, code enforcement often relies on a complaint-based system, whereby peers or supervisors who observe misconduct can file code violations (Beets and Killough 1990). Establishing reporting and accounting systems (e.g., to track corrupt behavior) can also create indirect monitoring effects, as these systems enhance transparency around misconduct and make it easier to govern individuals (Miller and O'Leary 1987). Organizational members often internalize the resulting pressures to comply with the provisions of a code, making self-monitoring another way to improve code effectiveness.

Most firms combine monitoring with sanctioning when trying to enforce their codes. Existing research has largely focused on negative sanctions, such as cessation of employment, monetary fines, verbal warnings, and legal actions (Singh 2011b). Of course, codes just contain a promise of sanction, while it is unclear whether organizations really deliver on the promise (Weaver 1995). Even when sanctions are not explicitly used as an organizational element, it is possible that individuals will nevertheless assume that sanctions exist. This is because people often hold expectations based on their prior knowledge about the general role of sanctions in organizations (Treviño and Ball 1992). Hence, even the absence of this organizational element can potentially support the organization of CSR, arguably as long as the absence is not revealed. Conversely, organizations can bring positive sanctions in the 
form of individual rewards, including for meeting CSR expectations.

\section{Organizing CSR Through Partial Organization}

Organizing for CSR has also happened to a large extent outside and among formal organizations-i.e., by various types of partial organization. We focus on two types of partial organization in the CSR context: (a) CSR standards and (b) cross-sector partnerships, as both have been part and parcel of the discussion of CSR in recent years (see the overviews by Austin and Seitanidi 2012 as well as Kourula and Laasonen 2010). While much has been written about both topics, surprisingly little research discusses the existence, absence and mixture of the above-mentioned organizational elements in the context of these types of partial organization. In the following, we discuss CSR standards and cross-sector partnerships and outline how both types of partial organization use certain organizational elements and disregard or are not able to employ others. We argue that ignoring some organizational elements can be advantageous for organizing CSR in specific circumstances making partial organization a deliberate choice for organizers.

\section{CSR Standards}

Standards in their most general sense reflect "rule[s] for common and voluntary use, decided by one or several people or organizations." (Brunsson et al. 2012, p. 616) Over the last two decades, many such rules have emerged in the CSR field, ranging from broadly defined principles (e.g., the UN Global Compact) to more narrowly defined certification standards (e.g., Social Accountability 8000) and guidelines for reporting (e.g., the Global Reporting Initiative). Recently, the International Organization for Standardization (ISO) entered the CSR field by releasing ISO 26000, a standard providing guidance on how different types of organizations can operate in socially responsible ways (Tamm Hallström 2008). Although CSR standards differ in many ways and are designed for a variety of purposes, they all reflect voluntary predefined rules for assessing, measuring, and communicating social and environmental performance (Rasche and Esser 2006).

Few CSR standards have restrictions regarding which organizations can adopt their rules. While some sectorspecific initiatives are by definition limited to participants from a certain industry, most standards are open in terms of their membership. However, CSR standards differ with regard to their membership strategies. Some standards operate as "clubs" to which participants have to sign up in order to become a member (Rasche 2012). For instance, organizations have to sign up to the Fair Labor Association to reap the benefits of membership. Companies also submit for consideration by the Dow Jones Sustainability Index. This makes these standards an excludable good (Prakash and Potoski 2006). Such a "closed" membership strategy can have positive social identity effects, as members feel part of a (more or less) exclusive club working toward a common purpose (Brewer 1993). Where companies derive reputational advantage from being members of standards, they will occasionally seek to protect this by excluding members who they consider to be temporarily falling short of the standard's requirements (e.g., Primark and the Ethical Trading Initiative). Other standards have decided to deliberately ignore membership as an organizational element. For instance, firms cannot sign up to become part of ISO 26000 or the Global Reporting Initiative (although firms can register their reports). In contrast to the Dow Jones example (above), the FTSE4Good Index, while restricted to the pool of listed companies, evaluates all in this pool and listing is not based on application but on monitoring (Slager et al. 2012). Ignoring membership as an organizational element can be advantageous, as it lowers entry barriers and hence can positively influence adoption rates. The swift growth of the Global Reporting Initiative into the de facto standard for non-financial reporting is a case in point (Etzion and Ferraro 2010).

As CSR standards are by definition voluntary, they are not based on forced obligations to comply with their underlying rules. In this sense, CSR standards do not depend on hierarchy as an instrument of organizing; they emphasize compliance rather than coercion. The organization adopting the standard has the main responsibility for insuring that the rules are followed, while in the context of law the responsibility for enforcement lies primarily with the rule setter (i.e., the state). This delegation of implementation authority to standard followers is often considered to be a key characteristic of soft law (Abbott et al. 2000). The absence of the right to force others into standard adoption is a mixed blessing for CSR standards. On the one hand, it allows for higher degrees of contextualization and flexibility, as the complier usually makes the final decision about how to fit the rules of the standard into the particular organizational context (Ahrne and Brunsson 2011). On the other hand, this flexibility can also be misused leading to accusations of standard adopters not walking their talk (Behnam and MacLean 2011).

While CSR-related rules within formal organizations tend to be very specific, since they need to account for the circumstances of a particular organizational context, the rules underlying CSR standards are often less precise, because they are supposed to be universally valid. Many standards address problems that cut across nation states and thus promote rules that are applicable in different geographic contexts, often taking existing international treaties or declarations as a point of reference (Leipziger 2003). 
For instance, the rules promoted by the FLA are based on universally recognized conventions by the International Labor Organization (ILO). Such universal rules offer a two-edged sword, however. One the one hand, they enable responsible behavior on a global scale and hence level the playing field. On the other hand, generalized rules always call for further contextualization within the process of application (Ortmann 2010).

Numerous standards ignore monitoring and sanctioning as organizational elements. For instance, ISO 26000 highlights that the standard is non-certifiable and thus does not contain any monitoring or sanctioning mechanisms (ISO 2010). While the decision to abstain from monitoring and sanctioning is often a political one, also depending on the nature of the standard itself (Rasche 2010, 2009), some standard setters can achieve high levels of compliance because they are themselves considered legitimate actors, making it risky for adopters to violate the standard. Standard setters often weigh the costs associated with adding further organizational elements like monitoring/sanctioning and the associated benefits, particularly when considering that monitoring itself cannot always guarantee higher compliance levels (e.g., because of sloppy audit practices; O'Rourke 2002). Even those standards that are explicitly set up to audit factories often outsource monitoring and sanctioning to other organizations. Social Accountability 8000, for instance, relies on professional certification bodies to carry out the audits (Gilbert and Rasche 2007). Since monitoring is a costly and time-consuming practice, this division of labor creates many advantages, as different organizers apply complementary organizational elements. However, some standards rely upon monitoring and the sanction of inclusion/exclusion, as in the case of the FTSE4Good which has neither membership nor hierarchy (Slager et al. 2012). Monitoring and sanctioning are not necessarily bound together. There can be monitoring without explicit sanctioning, such as when relying on implicit sanctions through reputation mechanisms.

\section{Cross-sector Partnerships}

Partial organization for CSR can also happen through cross-sector partnerships. Many definitions are available of such partnerships and closely related concepts (Googins and Rochlin 2000; Seitanidi and Crane 2009; Selsky and Parker 2005). One general definition of partnerships in a CSR context is "collaborative arrangements in which actors from two or more spheres of society (state, market, and civil society) are involved in a non-hierarchical process, and through which these actors strive for a sustainability goal." (van Huijstee et al. 2007, p. 77) Cross-sector approaches to CSR have in common that they involve collaborative efforts across business, government, and civil society but they, just like standards, come in many different forms. As van Huijstee et al. (2007) note in their review, partnerships are attributed a lot of different roles in the literature, from agenda setting to policy development and implementation, or from market creation to dissemination of knowledge.

First, we should reflect on the notion of membership. To engage in a partnership, at least two partners are required but not every organization can become a partner and not every collaboration results in a partnership. According to Googins and Rochlin (2000), important elements in creating mutually beneficial relationships include clear goals, senior level commitment, frequent communication, involvement of professionals, a shared commitment of resources, and an evaluation of progress. Quite a few publications present stage models to describe the development of partnerships, often from selection to design and institutionalization (Selsky and Parker 2005), but calls are also issued to conduct more micro-based studies to unpack these different stages (Seitanidi and Crane 2009). Such an approach can contribute to understanding the way membership varies in partnerships across sectors and why this variation would be beneficial for (one of) the partners.

As the definition of van Huijstee et al. (2007) already emphasized, cross-sector partnerships usually are nonhierarchical forms of organizing. Although hierarchies may not be fully absent they are less evident in partnerships which put more emphasis on consensus-based decisions. Where governments are members of partnerships, their hierarchical position is usually parenthetical to the operation of the partnership (e.g., the UK CSR Academy), whereas their imprimatur, and fiscal and organizational resources are more central (Moon and Vogel 2008). Yet, although formal hierarchies are less present in partnerships, there often are power differences among partners that affect, for instance, the availability of information or the influence in negotiation processes. Some authors, for instance, argue that "[t]he successful development of supply chain partnerships for sustainability tends to involve [...] a high concentration of powerful agents and the marginalization of smaller and less powerful agents." (Nikoloyuk et al. 2010, p. 70)

Rules are relevant in partnerships in several ways. On the one hand, there are internal rules, governing the partnership and defining, for instance, membership. Although some formal rules can exist, often there are no clear guidelines available on how to operate within a partnership. Babiak and Thibault (2008), for instance, note that in crosssector partnerships performance measures often are unclear. This absence of clarity allows for flexibility but could also backfire when one partner gets dissatisfied and decides to abandon the partnership. Egels-Zandén and Wahlqvist (2006, p. 176) speak of post-partnership 
strategies in this respect, deployed by firms that "seem to have grown tired of what are, in their eyes, inefficient and unproductive cross-sectoral partnerships." On the other hand, there are more external rules that are relevant for partnerships, for instance when these rules are the result of negotiations with NGOs on self-regulation (Pattberg 2005). The establishment of self-regulation in interaction with the wider environment involves elements of organizing but often also requires a lack of hierarchy to establish a level playing field for participating in the development process. Roundtables are one way to establish such self-regulation, as participants can be considered to be more or less equal such as in the Roundtable of Sustainable Palm Oil (RSPO) (Nikoloyuk et al. 2010).

Having rules available, and mutually agreed upon, is one thing but enforcing them is another. This leads to the notions of monitoring and sanctioning. "If a partnership is organized only with membership and rules, it will be up to the members themselves to monitor and sanction each other. Some members may reduce their cooperation with another member if they learn that this member does not follow the rules." (Ahrne and Brunsson, 2011 p. 94) One element often discussed in terms of monitoring is how to determine the value creating ability of partnerships. All participants in a partnership must have an idea of how their participation is going to generate value for them (Googins and Rochlin 2000). Yet, determining such value and thus monitoring the effectiveness of a partnership is not an easy task. As Austin and Seitanidi (2012) indicate, in different partnerships different measures are applied, arguably because these measures fit best with the particular partners' objectives. The fact that different measures can be applied in monitoring gives partners a considerable degree of freedom in emphasizing one issue over another, as long as the partners involved all agree.

In addition, partners will also closely monitor the results of their fellow partners to see whether every participant is living up to the expectations. Accountability, measurable targets and timetables, and reporting and monitoring mechanisms hence are listed as important elements for successfully organizing partnerships (Bäckstrand 2006). According to Bäckstrand (2006, p. 303): "Plural forms of accountability are needed to match the plural and amorphous features of global multi-sectoral partnerships." She speaks of "horizontal accountability (market, reputational and peer accountability)" and notes that "this fits the flexible and decentralized features of partnerships." (Bäckstrand 2006, p. 300) Such a flexible character of monitoring complicates the final element of organization, sanctioning, as the outcomes of monitoring usually form the reason to sanction. Meanwhile, the way partnerships are constructed often includes only limited sanctioning power for its participants. As Glasbergen (2011, p. 7) notes: "sanctions for failing to comply are often restricted to expulsion from the partnership." Although such a strategy seems to be a fairly weak sanction, being expelled from a partnership might have serious consequences in terms of reputation and credibility (Glasbergen 2011). Yet, one could question how easily such a sanction is applied and what alternatives are available to correct fellow partners.

\section{New Research Directions: Organizing for CSR}

Bearing these thoughts on complete and partial organization in mind, we now introduce the papers of this Special Issue and discuss their contributions. They can be grouped into three categories: papers discussing communication and the organization of CSR, papers reflecting on the context of organizing CSR, and papers concerned with the role of activists in the organization of CSR.

Two papers emphasize how communication affects organizing for CSR. Brennan et al. (2013) conceptualize CSR communication as a process of reciprocal influence between organizations and their audiences. Based on insights from linguistics they focus on different aspects of dialogism to examine the nature and type of verbal interactions between different parties in a conflict. They argue that CSR communication is an interactive process that has to be understood as a function of the power relations between a firm and a specific stakeholder. Related to this approach, Schultz et al. (2013) build on the communication constitutes organization (CCO) perspective (e.g., Christensen and Cornelissen 2011) to view CSR as communicatively constructed in dynamic interaction processes in networked societies. They discuss the potentially indeterminate, disintegrative, and conflictual character of CSR and challenge established views on CSR for not sufficiently acknowledging communication dynamics. They contend that this leads to a variety of biases and discuss implications of these biases.

With their emphasis on communication as a central element in organizing CSR, both papers touch on partial organization. Viewing CSR as constructed through communication and highlighting the role of dialogism and interaction processes implies a focus on power relations and conflict. The interaction process is not organized completely and therefore leaves room for discretion and adjustment. It is the contested area not fully organized that leaves room for debate, for dissent and for alternative interpretations. In emphasizing the importance of conceptualizing CSR communication as dialogical and interactive, such work can provide new insights on the process of institutionalizing CSR practices.

Two papers address contextual features affecting how CSR is organized. Baumann-Pauly et al. (2013) study how 
firm size affects the organization of CSR. Based on a comparative study of Swiss MNCs and SMEs, they argue that small firms possess several organizational characteristics that promote the implementation of CSR-related practices in core business functions, but, at the same time, constrain external communication and reporting. By contrast, MNCs possess characteristics that are favorable for promoting external communication and reporting, but, at the same time, constrain internal implementation. Gond and Boxenbaum (2013) study how responsible investment practices were imported in two different geographical regions and were adapted to these local settings. They show how actors employed three types of contextualization work (filtering, repurposing, and coupling) in both geographical settings to overcome the lack of technical, cultural, or political fit between the imported practice and their local context.

Whereas the paper by Baumann-Pauly et al. (2013) focuses on complete organization to learn how differences in formal organizations lead to different ways of organizing CSR, the paper by Gond and Boxenbaum (2013) clearly takes a partial organization perspective as it highlights how different actors try to adapt practices to a local context, requiring them to deviate from standards and to engage in deliberate engineering practices. The paper by BaumannPauly et al. (2013) is the most focused on complete organization, providing a comparative study to examine how different forms of organization play out in different contexts. This demonstrates how a systematic comparison between organizations based on their formal organizational elements can lead to useful insights on the organization of CSR. Gond and Boxenbaum (2013) focus on the explicit use of partial organizing, highlighting how this creates room for contextualizations. The more "completely" the responsible investment practices are organized, the less room they leave for local flavoring and adaptation.

The final three papers examine interactions between firms and civil society organizations. Arenas et al. (2013) suggest that it is important to examine the role of third parties in understanding collaboration between firms and civil society organizations. They analyze the presence of third parties and their different roles to explain how collaboration is facilitated. Burchell and Cook (2013) examine the theoretical implications of the changing relationships between NGOs and businesses that have emerged as a response to the evolving agenda around CSR and sustainable development. They do so by focusing on a process of appropriation and co-optation of protest by the business community. In identifying an alternative approach, they build on Chantal Mouffe's (1999) work to illustrate the way in which agonistic relationships are emerging between NGOs and businesses. Finally, Whelan (2013) introduces the notion of "dissensual CSR" to examine how this type of CSR is concerned with organizing corporate-civil society disagreement. Building on institutional theory and highlighting an economic perspective, he analyses a dissent enabling public sphere that Shell has constructed, and within which Greenpeace participated.

These three papers focus on the relationship between civil society and firms. Whereas Arenas et al. (2013) stress the importance of overcoming the dichotomy between collaboration and confrontation, the other two papers take a more critical stance, emphasizing the importance of conflict and dissensus. Burchell and Cook (2013), for instance, argue for a perspective on engagement reaching beyond an understanding of CSR as co-optation. Although research increasingly stresses the importance of collaboration, increasingly more critical approaches of CSR appear (Banerjee 2008; Levy 2008). Regardless of the ideological position, this stream of research indicates how the position of civil society toward firms remains an issue for debate. The three papers together provide insight into potential criticism of partial organization for CSR.

\section{Toward a Future Research Agenda}

Our paper connects recent work on the nature of organizing (Ahrne and Brunsson 2011) to the study of CSR. The presence of five organizational elements (membership, hierarchy, rules, monitoring, and sanctions) defines complete organization, while partial organization involves the absence of one or more of these elements. We maintain that it is useful to analytically distinguish different modes of organizing for CSR along the dimension of complete-partial organization. We suggest that a general shift from almost exclusive complete organization of CSR to a mixed picture with much more partial organization is a crucial feature of the more general trends of CSR from being "corporate-centered" to more "corporate-oriented", and the increasing institutionalization of CSR not only within business but also among non-governmental, governmental, and professional actors.

Adding the idea of partial organization allows CSR scholars to explore the division of labor between different organizers such as standard setters, consultants, or auditors. Ignoring certain organizational elements can provide organizers with much-needed room for maneuvering which allows the actors involved to look for common ground. Less complete forms of organizing are less formal and therefore sometimes easier to promote among, for instance, potential partners (who may be erstwhile adversaries) in partnerships. This adds to approaches in the literature that present the organization of CSR as a political process where new, and potentially less organized, forms of governance are proposed (Moon et al. 2004; Fransen 2012; Pattberg 2005). 
This view on organizing connects with institutional theory, which is applied widely in the CSR field to understand how different actors influence processes of institutional change. Interaction processes between actors often take time before they result in institutional change, if they do so at all. Organization can be expected to reflect a quicker method for creating change than trying to influence institutions directly (Ahrne and Brunsson 2011, p. 96). For instance, those aiming at changing institutionalized practices like non-financial reporting rarely have the time to wait for processes of socialization to change taken-forgranted behavior. Rather, they try to influence existing practices by introducing partial organization (e.g., standards). Recent attempts to change traditional "sustainability reporting" into "integrated reporting" via a new standard, the International Integrated Reporting Framework, is a case in point. Understood in this way, it is possible to organize institutions and hence introduce a certain level of control over them - the study by Gond and Boxenbaum (2013) provides an example of such institutional work, but more research is needed to unpack these processes.

These considerations point at several directions for future research. First of all, the relationship between complete and partial organization and processes of institutionalization requires further work. Why are certain organizational forms used more frequently to institutionalize CSR activities, while other forms are less widespread? Studies could focus on the role of specific elements of organizing and their role in processes of institutionalization: how do rules or sanctions guide the institutionalization of norms and standards in CSR and, specifically, how necessary is the presence of all five elements of organization? Could successful institutionalization occur without, say, membership or hierarchy? Future research needs to clarify how the presence or absence of organizational elements facilitates or hampers the institutionalization of CSR practices.

Second, future scholarly work can examine in what ways the conduct of CSR influences selected organizational elements. While the arguments presented in this paper show how the use and mix of different organizational elements influence the way CSR is organized, it is also possible to examine how CSR practices change these elements over time. For instance, firms with well-developed CSR practices often attract a special kind of workforce changing the membership of the organization. This emphasizes that the relationship between organizing and CSR is not linear but recursive.

Third, research needs to further examine the role of nonbusiness actors in processes of organizing for CSR. NGOs or other civil society organizations are often able to stimulate CSR initiatives. However, these tactics are usually not studied from the perspective of partial organization; Haug's (2013) recent paper is one exception. Focusing on a partial organization perspective could contribute to a more detailed understanding of how tactics for influencing organizations work and how interaction processes between firms and activists unfold when not all formal organizational elements are present.

Fourth, future research should highlight the dynamics of organizing for CSR. For instance, the types of partial organization, which are used to address social and environmental issues, change over time (e.g., the Marine Stewardship Council started out as a partnership between WWF and Unilever and then turned into a standard). Why do organizers move from one type of partial organization to another? What influences the adoption of certain types of partial organization over time? And in what ways does the movement of a social or environmental topic along the issue life cycle influence types of organizing?

Although we do not argue that the five organizational elements discussed in this paper represent a conclusive list, they provide a meaningful point of departure to discuss the relevance of organization in the context of CSR. Taking an alternative view on the role of organization within CSR leads to a different take on how corporate responsibilities are formed and how they influence a firm. With this paper we have only started to unpack the questions associated with this organization-focused approach to CSR; we look forward to reading further empirical studies in this direction.

Acknowledgments We wish to thank Journal of Business Ethics Associate Editor Thomas Maak for his support and guidance throughout this project. We are also grateful to the following colleagues who provided helpful comments on the ideas expressed in this paper: Frank den Hond, Dirk Ulrich Gilbert, Arno Kourula, Dirk Matten, Laura Spence, and Steen Vallentin as well as to the participants of the 2011 EGOS subtheme on "Organizing Corporate Social Responsibility: Interactions Between Business and Society." The seven papers included in this Special Issue were selected from 49 submissions. The reviewers, who deserve credit for their constructive comments and suggestions, included: Philip Balsiger, Dorothea Baur, Stephen Brammer, Edward Carberry, Robert Caruana, Nikolay Dentchev, Jonathan Doh, Neil Eccles, Gabriel Eweje, Giana Eckhardt, Peter Edward, Sabine Einwiller, George Frynas, Dirk Ulrich Gilbert, Margaret Griesse, Patrick Haack, Peter Hofman, Uwafiokun Idemudia, Øyvind Ihlen, Dima Jamali, Heledd Jenkins, Deanna Kemp, Céline Louche, Stephan Manning, Stefanie Mauksch, Sébastien Mena, Judy Muthuri, Ben Neville, André Nijhof, Guido Palazzo, Stephen Pavelin, Matteo Pedrini, Lars Rademacher, Jorge Rivera, Juliane Reinicke, Robert Rolfe, Darryl Reed, Lisbeth Segerlund, May Seitanidi, Jason Stansbury, Erica Steckler, Peter Lund Thomsen, Michael Valente, and Daniel Wäger.

\section{References}

Abbott, K. W. (2012). Engaging the public and the private in global sustainability governance. International Affairs, 88(3), 543-564. 
Abbott, K. W., Keohane, R. O., Moravcsik, A., Slaughter, A.-M., \& Snidal, D. (2000). The concept of legalization. International Organization, 54(3), 401-419.

Aguinis, H., \& Glavas, A. (2012). What we know and don't know about corporate social responsibility: A review and research agenda. Journal of Management, 38(4), 932-968.

Ahrne, G. (1994). Social organizations: Interaction, inside, outside and between organizations. London: Sage.

Ahrne, G., \& Brunsson, N. (2011). Organization outside organizations: The significance of partial organization. Organization, 18(1), 83-104.

Arenas, D., Sanchez, P., \& Murphy, M. (2013). Different paths to collaboration between businesses and civil society and the role of third parties. Journal of Business Ethics. doi:10.1007/s10551013-1829-5

Ashforth, B. E., \& Mael, F. (1989). Social identity theory and the organization. Academy of Management Review, 14(1), 20-39.

Austin, J. E., \& Seitanidi, M. M. (2012). Collaborative value creation: A review of partnering between nonprofits and businesses: Part I. Value creation spectrum and collaboration stages. Nonprofit and Voluntary Sector Quarterly, 41(5), 726-758.

Babiak, K., \& Thibault, L. (2008). Challenges in multiple cross-sector partnerships. Nonprofit and Voluntary Sector Quarterly, 38(1), $117-143$.

Bäckstrand, K. (2006). Multi-stakeholder partnerships for sustainable development: rethinking legitimacy, accountability and effectiveness. European Environment, 16(5), 290-306.

Banerjee, S. B. (2008). Corporate social responsibility: The good, the bad and the ugly. Critical Sociology, 34(1), 51-79.

Basu, K., \& Palazzo, G. (2008). Corporate social responsibility: A process model of sensemaking. Academy of Management Review, 33(1), 122-136.

Baumann-Pauly, D., Wickert, C., Spence, L. J., \& Scherer, A. G. (2013). Organizing corporate social responsibility in small and large firms: Size matters. Journal of Business Ethics. 10.1007/ s10551-013-1827-7

Beets, S. D., \& Killough, L. N. (1990). The effectiveness of a complaint-based ethics enforcement system: Evidence from the accounting profession. Journal of Business Ethics, 9(2), $115-126$.

Behnam, M., \& MacLean, T. L. (2011). Where is the accountability in international accountability standards? A decoupling perspective. Business Ethics Quarterly, 21(1), 45-72.

Berger, P., \& Luckmann, T. (1966). The social construction of reality: A treatise in the sociology of knowledge. Garden City: Doubleday.

Bondy, K., Moon, J., \& Matten, D. (2012). An institution of corporate social responsibility (CSR) in multi-national corporations (MNCs): form and implications. Journal of Business Ethics, 111(2), 281-299.

Brennan, N. M., Merkl-Davies, D. M., \& Beelitz, A. (2013). Dialogism in corporate social responsibility communications: Conceptualizing verbal interaction between organisations and their audiences. Journal of Business Ethics. doi:10.1007/s10551013-1825-9

Brewer, M. B. (1993). Social identity, distinctiveness, and in-group homogeneity. Social Cognition, 11(1), 150-164.

Brickson, S. (2007). Organizational identity orientation: The genesis of the role of the firm and distinct forms of social value. Academy of Management Review, 32, 864-888.

Brunsson, N. (2006). Mechanisms of hope: Maintaining the dream of the rational organization. Malmö: Copenhagen Business School Press.

Brunsson, N., Rasche, A., \& Seidl, D. (2012). The dynamics of standardization: Three perspectives on standards in organization studies. Organization Studies, 33, 613-632.
Burchell, J., \& Cook, J. (2013). CSR, co-optation and resistance: The emergence of new agonistic relations between business and civil society. Journal of Business Ethics. doi:10.1007/s10551-013$1830-\mathrm{Z}$

Burns, J. M. (1979). Leadership. New York: Harper Torchbooks.

Carroll, A. B. (1979). A three-dimensional conceptual model of corporate performance. Academy of Management Review, 4(4), 497-505.

Carroll, A. B., \& Shabana, K. M. (2010). The business case for corporate social responsibility: A review of concepts, research and practice. International Journal of Management Reviews, 12(1), 85-105.

Chapple, W., \& Moon, J. (2005). Corporate social responsibility (CSR) in Asia: A seven country study of CSR website reporting. Business and Society, 44(4), 415-441.

Child, J. (2005). Organization: Contemporary principles and practice. Malden: Blackwell.

Christensen, L. T., \& Cornelissen, J. P. (2011). Bridging corporate and organizational communication: Review, development and a look to the future. Management Communication Quarterly, 25(3), 383-414.

Coleman, W. D. (1997). Associational governance in a globalizing world: Weathering the storm. In J. R. Hollingsworth \& R. Boyer (Eds.), Contemporary capitalism: The embeddedness of institutions (pp. 127-153). Cambridge: Cambridge University Press.

de Bakker, F. G. A. (2012). Exploring networks of activism on corporate social responsibility: Suggestions for a research agenda. Creativity \& Innovation Management, 21(2), 212-223.

de Bakker, F. G. A., den Hond, F., King, B. G., \& Weber, K. (2013). Social movements, civil society and corporations: Taking stock and looking ahead. Organization Studies, 34(5-6), 573-593.

de Bakker, F. G. A., Groenewegen, P., \& den Hond, F. (2005). A bibliometric analysis of 30 years of research and theory on corporate social responsibility and corporate social performance. Business \& Society, 44(3), 283-317.

den Hond, F., \& de Bakker, F. G. A. (2007). Ideologically motivated activism. How activist groups influence corporate social change. Academy of Management Review, 32(3), 901-924.

Egels-Zandén, N., \& Wahlqvist, E. (2006). Post-partnership strategies for defining corporate responsibility: The business social compliance initiative. Journal of Business Ethics, 70(2), 175-189.

Etzion, D., \& Ferraro, F. (2010). The role of analogy in the institutionalization of sustainability reporting. Organization Science, 21(5), 1092-1107.

Etzioni, A. (1964). Modern organizations. Englewood Cliffs: Prentice-Hall.

European Commission. (2011). A renewed EU strategy 2011-2014 for corporate social responsibility, COM (2011) 681 final. Brussels: European Commission.

Fransen, L. (2012). Multi-stakeholder governance and voluntary programme interactions: Legitimation politics in the institutional design of corporate social responsibility. Socio-Economic Review, 10, 163-192.

Garriga, E., \& Melé, D. (2004). Corporate social responsibility theories: Mapping the territory. Journal of Business Ethics, 53(1), 51-71.

Gilbert, D. U., Rasche, A., \& Waddock, S. (2011). Accountability in a global economy: The emergence of international accountability standards. Business Ethics Quarterly, 21(1), 23-44.

Gilbert, D. U., \& Rasche, A. (2007). Discourse ethics and social accountability: The ethics of SA 8000 . Business Ethics Quarterly, 17(2), 187-216.

Glasbergen, P. (2011). Understanding partnerships for sustainable development analytically: The ladder of partnership activity as a methodological tool. Environmental Policy and Governance, 21(1), 1-13. 
Gond, J.-P., \& Boxenbaum, E. (2013). The glocalization of responsible investment: Contextualization work in France and Quebec. Journal of Business Ethics. doi:10.1007/s10551-013-1828-6

Gond, J.-P., Kang, N., \& Moon, J. (2011). The government of selfregulation: on the comparative dynamics of CSR. Economy and Society, 40(4), 640-671.

Gond, J.-P., \& Moon, J. (2011). Corporate social responsibility in retrospect and prospect. In J.-P. Gond \& J. Moon (Eds.), Corporate social responsibility: A reader (pp. 1-28). London: Routledge.

Googins, B. K., \& Rochlin, S. A. (2000). Creating the partnership society: Understanding the rhetoric and reality of cross-sectoral partnerships. Business and Society Review, 105(1), 127-144.

Granovetter, M. S. (1973). The strength of weak ties. American Journal of Sociology, 78(6), 1360-1380.

Haug, C. (2013). Organizing spaces: Meeting arenas as a social movement infrastructure between organization, network, and institution. Organization Studies, 34(5-6), 705-732.

Holder-Webb, L., \& Cohen, J. (2012). The cut and paste society: Isomorphism in codes of ethics. Journal of Business Ethics, 107(4), 485-509.

Huntington, S. P. (1968). Political order in changing societies. New Haven: Yale University Press.

Husted, B. W. (2003). Governance choices for corporate social responsibility: To contribute, collaborate or internalize? Long Range Planning, 36, 481-498.

International Organization for Standardization (ISO) (2010). ISO 26000:2010 guidance on social responsibility. ISO, Geneva.

Jamali, D., Zanhour, M., \& Keshishian, T. (2009). Peculiar strengths and relational attributes of SMEs in the context of CSR. Journal of Business Ethics, 87, 355-377.

Kaptein, M., \& Schwartz, M. (2008). The effectiveness of business codes: A critical examination of existing studies and the development of an integrated research model. Journal of Business Ethics, 77(2), 111-127.

Kourula, A., \& Laasonen, S. (2010). Nongovernmental organizations in business and society, management, and international business research: Review and implications from 1998 to 2007. Business \& Society, 49(1), 35-67.

Langlois, C., \& Schlegelmilch, B. (1990). Do corporate codes of ethics reflect national character? Evidence from Europe and the United States. Journal of International Business Studies, 21, 519-539.

Leipziger, D. (2003). The corporate responsibility codebook. Sheffield: Greenleaf Publishing.

Levy, D. L. (2008). Political contestation in global production networks. Academy of Management Review, 33(4), 943-963.

Lockett, A., Moon, J., \& Visser, W. (2006). Corporate social responsibility in management research: Focus, nature, salience and sources of influence. Journal of Management Studies, 43, 115-136.

Maignan, I., \& Ralston, D. (2002). Corporate social responsibility in Europe and the U.S.: Insights from businesses' self-presentations. Journal of International Business, 33(3), 497-514.

March, J. G., \& Simon, H. A. (1958). Organizations. New York: Wiley.

Matten, D., \& Moon, J. (2008). 'Implicit' and 'explicit' CSR: A conceptual framework for a comparative understanding of corporate social responsibility. Academy of Management Review, 33(2), 404-424.

McGuire, J. (1963). Business and society. New York: McGraw-Hill.

Miller, P., \& O'Leary, T. (1987). Accounting, and the construction of the governable person. Accounting, Organizations and Society, $12(3), 235-265$.

Mintzberg, H. (1979). The structuring of organizations. Englewood Cliffs: Prentice Hall.
Moon, J. (2014). Corporate social responsibility: A very short introduction. Oxford: Oxford University Press.

Moon, J. (2004). The institutionalisation of business social responsibility: Evidence from Australia and the UK. The Anahuac Journal (Mexico), 5(1), 40-54.

Moon, J., \& Vogel, D. (2008). Corporate social responsibility, government and civil society. In A. Crane, A. McWilliams, D. Matten, J. Moon, \& D. Siegel (Eds.), The Oxford handbook of corporate social responsibility (pp. 303-326). Oxford: Oxford University Press.

Moon, J., Crane, A., \& Matten, D. (2004). Can corporations be citizens? Corporate citizenship as a metaphor for business participation in society. Business Ethics Quarterly, 15(3), 427-451.

Mouffe, C. (1999). Deliberative democracy or agonistic pluralism? Social Research, 66(3), 745-758.

Nikoloyuk, J., Burns, T. R., \& De Man, R. (2010). The promise and limitations of partnered governance: The case of sustainable palm oil. Corporate Governance, 10(1), 59-72.

O'Rourke, D. (2002). Monitoring the monitors: A critique of corporate third-party labor monitoring. In R. Jenkins, R. Pearson, \& G. Seyfang (Eds.), Corporate responsibility and ethical trade: Codes of conduct in the global economy (pp. 196-208). London: Earthscan.

Ortmann, G. (2010). On drifting rules and standards. Scandinavian Journal of Management, 26(2), 204-214.

Pattberg, P. H. (2005). The institutionalization of private governance: How business and nonprofit organizations agree on transnational rules. Governance, 18(4), 589-610.

Peters, B. G. (1999). Institutional theory in political science: the new institutionalism. London: Pinter.

Petersen, L.-E., \& Krings, F. (2009). Are ethical codes of conduct toothless tigers for dealing with employment discrimination? Journal of Business Ethics, 85(4), 501-514.

Pless, N. M., Maak, T., \& Waldman, D. A. (2012). Different approaches toward doing the right thing: Mapping the responsibility orientations of leaders. Academy of Management Perspectives, 26(4), 51-65.

Prakash, A., \& Potoski, M. (2006). The voluntary environmentalists: Green clubs, ISO 14001, and voluntary environmental regulations. Cambridge: Cambridge University Press.

Rasche, A. (2012). Global policies and local practice: Loose and tight couplings in multi-stakeholder initiatives. Business Ethics Quarterly, 22(4), 679-708.

Rasche, A. (2010). The limits of corporate responsibility standards. Business Ethics: A European Review, 19(3), 280-291.

Rasche, A. (2009). 'A necessary supplement': What the United Nations Global Compact is and is not. Business \& Society, 48(4), 511-537.

Rasche, A., \& Esser, D. (2006). From stakeholder management to stakeholder accountability. Journal of Business Ethics, 65(3), 251-267.

Sauder, M., \& Espeland, W. N. (2009). The discipline of rankings: Tight coupling and organizational change. American Sociological Review, 74(1), 63-82.

Scherer, A. G., \& Palazzo, G. (2011). The new political role of business in a globalized world: A review of a new perspective on CSR and its implications for the firm, governance, and democracy. Journal of Management Studies, 48(4), 899-931.

Schultz, F., Castelló, I., \& Morsing, M. (2013). The construction of corporate social responsibility in network societies: A communication view. Journal of Business Ethics. doi:10.1007/s10551013-1826-8

Seitanidi, M., \& Crane, A. (2009). Implementing CSR through partnerships: Understanding the selection, design and institutionalization of nonprofit-business partnerships. Journal of Business Ethics, 85, 413-429. 
Selsky, J. W., \& Parker, B. (2005). Cross-sector partnerships to address social issues: Challenges to theory and practice. Journal of Management, 31(6), 849-873.

Singh, J. B. (2011a). Determinants of the effectiveness of corporate codes of ethics: An empirical study. Journal of Business Ethics, 101, 385-395.

Singh, J. B. (2011b). Changes and trends in Canadian corporate ethics programs. Business and Society Review, 116(2), 257-276.

Slager, R., Gond, J.-P., \& Moon, J. (2012). Standardization as institutional work: The regulative power of a responsible investment standard. Organization Studies, 33(5-6), 763-790.

Stevens, J. M., Steensma, H. K., Harrison, D. A., \& Cochran, P. L. (2005). Symbolic or substantive document? The influence of ethics codes on financial executives' decisions. Strategic Management Journal, 26(2), 181-195.

Strand, R. (2012). In praise of Corporate Social Responsibility bureaucracy. Copenhagen Business School PhD Series (26.2012), Copenhagen.

Strand, R. (2011). Exploring the role of leadership in corporate social responsibility: A review. Journal of Leadership, Accountability \& Ethics, 8(4), 84-96.

Tamm Hallström, K. (2008). ISO expands its business into social responsibility. In M. Boström \& C. Garsten (Eds.), Organizing transnational accountability (pp. 46-60). Cheltenham: Edward Elgar.

Thornton, P. H., Ocasio, W., \& Lounsbury, M. (2012). The institutional logics perspective: A new approach to culture, structure and process. New York: Oxford University Press.

Treviño, L. K., \& Ball, G. A. (1992). The social implications of punishing unethical behavior: Observers' cognitive and affective reactions. Journal of Management, 18, 751-768.

van Huijstee, M. M., Francken, M., \& Leroy, P. (2007). Partnerships for sustainable development: A review of current literature. Environmental Sciences, 4(2), 75-89.

Weaver, G. R. (1995). Does ethics code design matter? Effects of ethics code rationales and sanctions on recipients' justice perceptions and content recall. Journal of Business Ethics, 14(5), 367-385.

Weber, M. (1968). Economy and society. Berkeley: University of California Press.

Weick, K. E. (1979). The social psychology of organizing. Reading: Addison-Wesley.

Whelan, G. (2013). Corporate constructed and dissent enabling public spheres: Differentiating dissensual from consensual corporate social responsibility. Journal of Business Ethics. doi:10.1007/ s10551-013-1823-y 